\title{
PENERAPAN PERAWATAN LUKA MODERN DRESSING PADA LANSIA PENDERITA DIABETES MELITUS
}

\author{
Aliyyah Amanda ${ }^{1}$, Ricky Riyanto Iksan ${ }^{2 *}$, Sri Atun Wahyuningsih ${ }^{3}$ \\ 1,2,3Program Diploma Tiga Keperawatan Akademi Keperawatan Pelni Jakarta \\ Email Korespondesi: awliyyah22676@gmail.com
}

Disubmit: 17 Oktober 2021 Diterima: 05 Desember 2021 Diterbitkan: 01 Januari 2022 DOI: https://doi.org/10.33024/mnj.v1i1.5324

\section{ABSTRACT: APPLICATION OF MODERN DRESSING WOUND TREATMENT IN ELDERLY SUFFERERS DIABETES MELLITUS}

Backgound: Diabetes mellitus is a disease that is a health problem in the elderly. Diabetes mellitus is a chronic disease characterized by elevated levels of glucose in the blood.

Objective: This study aims to identify gangrene wound care with modern dressing methods in the elderly with diabetes mellitus.

Method: The research method used is a case study design, which is a form of research (inquiry) or case studies and interventions about a problem that hasa specific nature (particular arity).

Result: The results of the research conducted on the first respondent a score of 33 on the BWAT scale did not regenerate, the second respondent experienced the healing process a score of 10 , the third respondent did not regenerate with a score of 16, the fourth respondent did not regeneratewith a score of 20. Conclusion: The conclusions of this study describe the Modern Dressing wound care intervention in three respondents who did not have a generationof wound healing processes and one respondent experienced the wound healing process.

Keywords: Diabetes Mellitus, Elderly, Modern Dressing, Bwat Value 


\section{INTISARI: PENERAPAN PERAWATAN LUKA MODERN DRESSING PADA LANISA PENDERITA DIABETES MELITUS}

Latar Belakang : Diabetes melitus merupakan penyakit yang menjadi masalah kesehatan pada lanjut usia. Diabetes melitus Merupakan suatu penyakit kronis yang ditandai dengan peningkatan kadar glukosa dalam darah.

Tujuan: Penelitian ini bertujuan untuk teridentifikasi perawatan luka ganggren dengan metode modern dressing pada lansia dengan masalah diabetes melitus. Metode Penelitian : Metode penelitian yang digunakan case study design yaitu suatu bentuk penelitian (inquiry) atau studi kasus dan intervensi tentang suatu masalah yang memiliki sifat kekhususan (particul arity).

Hasil : Hasil penelitian yang dilakukan pada responden pertama skor 33 skala BWAT tidak bergenerasi, pada responden kedua mengalami proses penyembuhan skor 10, pada responden ketiga tidak bergenerasi dengan skor 16,pada responden keempat tidak beregenerasi dengan skor 20.

Kesimpulan : Simpulan dari penelitian ini menggambarkan Intervensi perawatan luka Modern Dressing pada tiga responden tidak bergenerasiproses penyembuhan luka dan satu responden mengalami proses penyembuhan luka.

Kata Kunci : Diabetes melitus, Lansia, Modern Dressing, BWAT score

\section{PENDAHULUAN}

Diabetes Melitus merupakan penyakit yang menjadi masalah kesehatan pada lanjut usia. Diabetes melitus Merupakan suatu penyakit kronis yang ditandai dengan peningkatan kadarglukosa dalam darah dan selalu disertai dengan komplikasi dari penderita diabetes melitus merupakan masalah kesehatan utama dalam masyarakat. (Supriyadi, 2017).

Ulkus diabetikum atau Luka diabetik adalah kondisi medis yang ditandai dengan lukacekung yang lama tidak menyembuh, dengan pembengkakan dan berbatas tegas.

Hal ini merupakan tanda umum dari diabetesyang tidak ter Konvesional pada penderita baik diabetes militus tipe 1 atau tipe 2 .

Pada pasien diabetes cendrung terjadi penyakit arteri perifer, suatu kondisi dimana terjadipenyumbatan pembuluh darah ditungkai dan neuropati perifer, suatu kondisi dimana terjadikerusakan saraf-saraf pada tungkai akibat kadar gula darah yang tinggi. (Nurhaida, 2019)
Prevalensi World Health Organization (WHO) tahun 2016. dari total kematian di dunia dan lebih dari setengah beban penyakit. 90-95\% darikasus Diabetes adalah Diabetes Tipe 2 yang sebagian besar dapat dicegah karena disebabkan oleh gaya hidup yang tidak sehat. International Diabet Federation (IDF) Atlas 2017 melaporkan bahwa epidemi Diabetes di Indonesia masih menunjukkan kecenderungan meningkat. Indonesia adalah negara peringkat keenam di dunia setelah Tiongkok, India, Amerika Serikat, Brazil dan Meksiko dengan jumlah penyandang Diabetes usia 20-79 tahun sekitar 10,3 juta orang. (Kementrian Kesehatan Republik Indonesia, 2018). 
Prevalensi diabetes (DM) di banten yang terdiagnosis dokter sebesar $1,3 \%$ dan 0,4\%. Diabetes melitus terdiagnosis dokter dan gejala sebesar $1,6 \%$. Prevalensi diabetes yang terdiagnosis dokter tertinggi maupun yang terdiagnosis dokter dan gejalatertinggi terdapat di empat kabupaten/kota yang sama, yaitu Kota Cilegon 2,2\% dan 2,8\%, Kota Tangerang 1,8\% dan 2,5\%, Kota Tangerang Selatan 1,7\% dan 1,9\% dan

Kabupaten Tangerang 1,4\%

dan 1,7\% (Kementrian Kesehatan Republik Indonesia , 2013).

Berdasarkan data laporan

Penderita Diabetes Melitus

Puskesmas Larangan Utara masih menjadi salah satu masalah di Puskesmas Kecamatan Larangan Utara, Diabetes Melitus merupakan urutan ketiga penyakit dari 10 dengan penderita terbanyak di Puskesmas Kecamatan Larangan Utara, sebanyak 2.488 penderita (Profil Puskesmas Kecamatan Larangan utara 2020 ).

$$
\text { Tanda gejala penderita }
$$

Diabetes melitus disebabkan Poliuri (banyak kencing) Poliuri merupakan gejala awal diabetes yang terjadi apabila kadar gula darah sampai di atas 160-180 $\mathrm{mg} / \mathrm{dl}$.

Kadar glukosa darah yang tinggi akan dikeluarkan melalui air kemih, jika semakin tinggi, Polidipsi (banyak minum) kemampuan insulin mengelolakadar gula dalam darah sehingga penderita merasakanlapar yang berlebihan (Kementerian Kesehatan Republik Indonesia, 2018).

Upaya pencegahan yang
dilakuaknoleh pemerintahan di
Indonesia komplikasi diabetes
mellitus yaitu ulkus diabetik karena
meningkatnya angka penderita
diabetes mellitus. Peningkatan
angka ulkus dikarenakan tidak

terkontrolnya kadar glukosa darah dan sirkulasi aliran darah yang tidak lancar.

Intervensi Perawatan luka dengan menggunakan prinsip moistue balance ini dikenal sebagai metode (modern dressing dan memakai alat ganti balut yanglebih modern). Metode tersebut belum begitu familiar bagi perawat di Indonesia.

Perkembanganperawatan luka (Wound Care) berkembang dengan sangat pesat di dunia kesehatan. Metode perawatan luka yang berkembang saat ini adalah perawatan luka dengan menggunakan prinsip moisture balance, dimana disebutkandalam beberapa literature lebih efektif untuk prosespenyembuhan luka bila dibandingkan dengan metode konvensional (Maghfuri, 2016).

Lanjut Usia adalah penduduk yang berusia 60 tahun ke atas. Menua atau menjadi tua adalah suatu proses menghilangnya secara perlahan, suatu jaringan untuk mempertahankan struktur dan fungsi normalnya, sehingga tidak dapat memperbaiki kerusakanyang diderita. Proses menua adalah proses yang pastiterjadi pada setiap orang,terjadi secara terus menerus secara alamiah, dimulai sejak lahir dan dialami oleh makhluk hidup (Dariah, 2015).

Menurut hasil penelitian yang dilakukan oleh Tiara (2012), pada pasien yang dilakukan perawatan luka dengan modern dressingdidapatkan penurunan skor derajat luka.

Sedangkan

konvensional akan waktu yang lebih waktu yang lebih lama dalam perawatan karena terjadinya perdarahan atau trauma ulang sebagai dampak dari penggantian balutan yang terlalu sering.

Menurut hasil penelitian 
Damsir (2018) bahwaperawatan luka menggunakan balutan modern dressing hasil lebih efektif dibandingkan dengan perawatan luka dengan balutan konvensional terhadap proses penyembuhanluka diabetik.

Sama halnya dengan penelitian yang dilakukan oleh Nurhaida (2017) bahwa adanya efektifitas terapi modern dressing terhadap proses penyembuhan luka kaki diabetik. Balutan konvensional kurang dapat menjaga kelembaban luka dikarenakan $\mathrm{NaCl}$ akan menguap dan membuat kasa menjadi kering.Berdasarkan studi pendahuluan yang dilakukan di puskesmas wilayah larangan utara didaptkan data berupa penderita ulkus diabetikum Puskesmas Larangan Utara masih menjadisalah satu masalah di Puskesmas KecamatanLarangan Utara, Diabetes Melitus merupakan urutan ketiga penyakit dari 10 terbesar di Puskesmas Kecamatan Larangan Utara,Data hasil Survey di Wilayah Inpres Iv Larangan Utaradidapatkan data distribusi salah satu penyakit adalahdiabetes dengan luka / ulkus diabetik sebanyak 46 penderita (Profil Puskesmas Kec. Larangan utara 2020).

Berdasakan uraian diatas peneliti tertarik untuk menyusun dan menganalisa bagaimana "Analisis Intervensi PerawatanLuka Ganggren dengan Metode Modern Dressing Pada Lansia Penderita Diabetes Melitus Di Wilayah Inpres IV Larangan Utara”.

\section{METODE PENELITIAN}

Jenis penelitian ini adalah penelitian case study design yaitu suatu bentuk penelitian (inquiry) atau studi kasus dan intervensi tentang suatu masalah yang memiliki sifat kekhususan (particularity)dengan tujuan untuk mempelajari secara intensif mengenai unit-unit sosial seperti perhimpunan, perorangan maupun kelompok, keluarga dan bahkan masyarakat luas. Menurut (Basuki, 2017). Pada penelitian ini peneliti melakukan intervensi perawatn luka modern dressing pada empat lansia dengan diabtes melitus dengan luka yaitukeempat penderita sama-sama diberikan terapi perawatn luka modern dressing

Pada penelitian ini peneliti melakukan intervensi latihan perawatn luka modern dressing dalam pelayanan dan asuhan keperawatan lansia penderita diabtes melitus dengan lukadengan karakteristik yang sama yaitu 4 klien sama-samadiberikan perawatn luka modern dressing dilakukan selama 30 menit, setiap $1 x$ sehari selama 8hari.

Hasil penelitian memenuhi syarat untuk di ujikan, peneliti sudah memenuhi uji proposal dan lulus dalam uji etik penelitian ini. 
HASIL

Karateristik Responden

Tabel 1

Distribusi Karakteristik Responden $(n=4)$ di Wilayah Inpres

04 Rw 06 Kelurahan Larangan Utara Kecamatan Larangan Tangerang selama 8 hari

\begin{tabular}{cccc}
\hline Responden & Umur & Jenis Kelamin & Stadium Luka \\
\hline Responden 1 & $62 \mathrm{Th}$ & Laki laki & II \\
Responden 2 & $57 \mathrm{Th}$ & Laki laki & \\
Responden 3 & $60 \mathrm{Th}$ & Laki laki & I \\
Responden 4 & $64 \mathrm{Th}$ & Perempuan & II
\end{tabular}

Sumber data primer 2021

Berdasarkan tabel 1 menunjukan bahwa gambaran umur dari ke 4 responden rata rata diatas usia 60 tahun. Dari 4 reseponden yang diteliti 3 diantaranya adalah laki laki dan 1 perempuan. Dengan rata rata stadium luka stadium II 50\% dan stadium I $50 \%$.

Pelaksanaa Intervensi dan Implementasu Keperawatan:

a. Hasil Penerapan Pertama

Responden 1

Tabel 1

Distribusi Pertemuan Pertama Pengkajian Luka dan Perawatan Luka Responden $(\mathrm{n}=4)$ Sebelum dan Sesudah Perawatan Luka di Rw 06 Kelurahan Larangan Utara Kecamatan Larangan Tangerang.

\begin{tabular}{|c|c|c|c|c|c|}
\hline $\begin{array}{l}\text { Hari } \\
\text { Pertemuan } \\
1-8\end{array}$ & Responden & $\begin{array}{l}\text { Sebelum } \\
\text { Perawatan } \\
\text { Luka }\end{array}$ & Keterangan & $\begin{array}{l}\text { Sesudah } \\
\text { Perawatan } \\
\text { luka }\end{array}$ & Keterangan \\
\hline $\begin{array}{l}\text { Minggu, } 6 \\
\text { juni } 2021\end{array}$ & $\begin{array}{c}1 \\
\text { Pukul } \\
10.00\end{array}$ & $\begin{array}{c}\text { Luka tampak } \\
\text { merah, Bau, } \\
\text { jaringan } \\
\text { disekitar luka } \\
\text { berwarna } \\
\text { hitam terasa } \\
\text { keras } \\
\text { Luka tampak }\end{array}$ & $\begin{array}{c}\text { Nilai : } \\
33 \\
\text { Tidak } \\
\text { beregenera } \\
\text { si }\end{array}$ & $\begin{array}{l}\text { Belum ada } \\
\text { perubahan }\end{array}$ & $\begin{array}{c}\text { Skor:33 } \\
\text { Tidak } \\
\text { beregene } \\
\text { rasi }\end{array}$ \\
\hline $\begin{array}{l}\text { Senin, } 7 \text { juni } \\
2021\end{array}$ & $\begin{array}{c}1 \\
\text { Pukul } \\
11.00\end{array}$ & $\begin{array}{c}\text { merah, Bau, } \\
\text { jaringan } \\
\text { disekitar luka } \\
\text { berwarna } \\
\text { hitam terasa } \\
\text { keras }\end{array}$ & $\begin{array}{c}\text { Nilai: } \\
33 \\
\text { Tidak } \\
\text { beregenera } \\
\text { si }\end{array}$ & $\begin{array}{l}\text { Bau luka } \\
\text { sedikit } \\
\text { berkura } \\
\text { ng }\end{array}$ & $\begin{array}{c}\text { Skor: } 33 \\
\text { Tidak } \\
\text { beregene } \\
\text { rasi }\end{array}$ \\
\hline $\begin{array}{l}\text { Selasa, } 8 \\
\text { juni } 2021\end{array}$ & $\begin{array}{c}1 \\
\text { Pukul } \\
10.00\end{array}$ & $\begin{array}{c}\text { Luka tampak } \\
\text { merah, Bau, } \\
\text { jaringan } \\
\text { nekrotik } \\
\text { disekitar luka } \\
\text { berwarna } \\
\text { hitam terasa } \\
\text { keras }\end{array}$ & $\begin{array}{c}\text { Nilai: } \\
33 \\
\text { Tidak } \\
\text { beregenera } \\
\text { si }\end{array}$ & $\begin{array}{c}\text { Bau luka } \\
\text { sedikit } \\
\text { berkurang }\end{array}$ & $\begin{array}{c}\text { Skor: } 33 \\
\text { Tidak } \\
\text { beregene } \\
\text { rasi }\end{array}$ \\
\hline
\end{tabular}




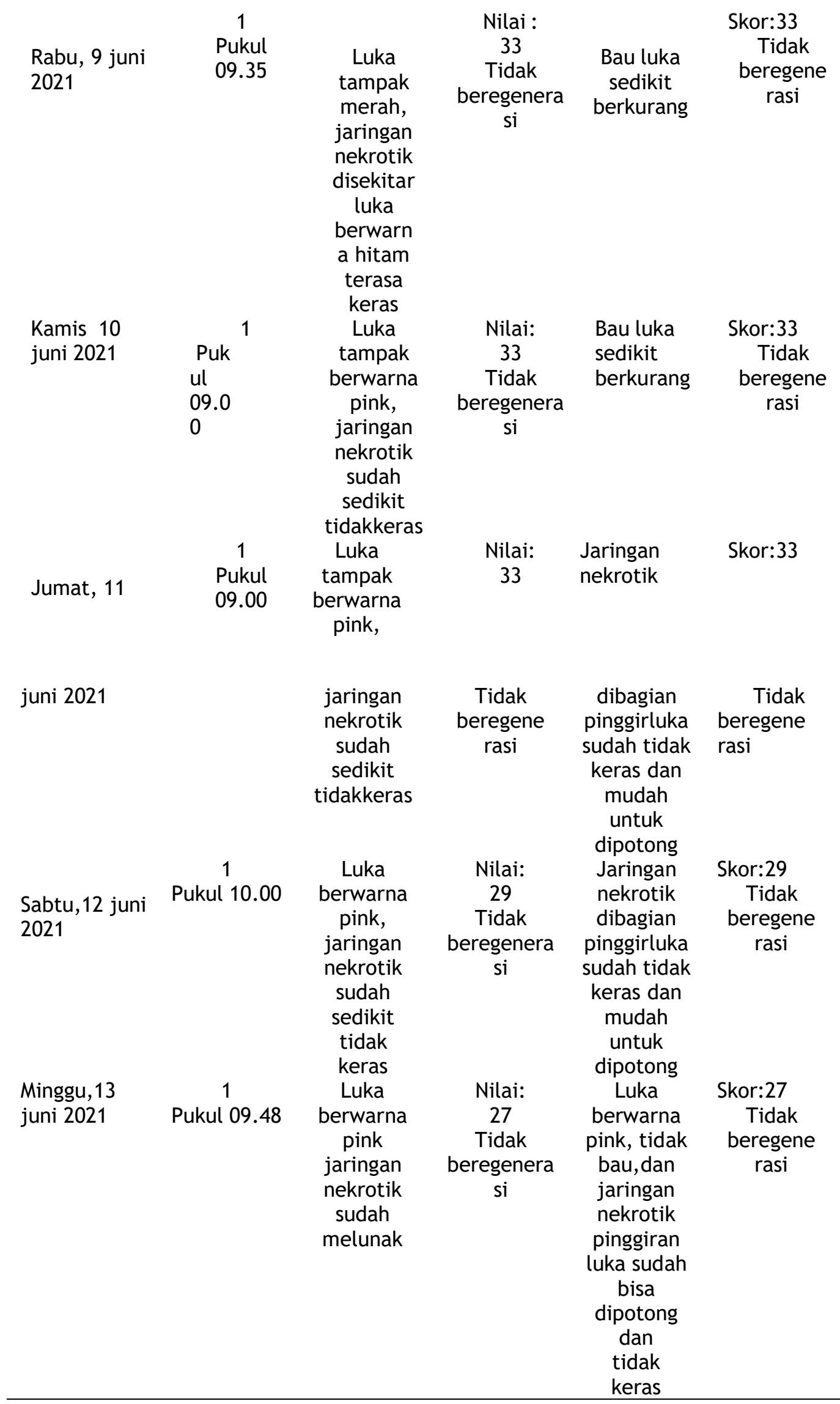


Hasil dari table 1 mengalami penurunan skor di hari ke 7 , dari skor 33 menjadi 27 dengan interprestasi tidak bergenerasi.

\section{Responden 2}

Tabel 2

Distribusi Pertemuan Pertama Pengkajian Luka dan Perawatan Luka Responden $(n=4)$ Sebelum dan Sesudah Perawatan Luka di wilayah Inpres IV Rw 06 Kelurahan Larangan utara Kecamatan Larangan Tangerang.

\begin{tabular}{|c|c|c|c|c|c|}
\hline $\begin{array}{l}\text { Hari } \\
\text { Pertemuan } \\
1-8\end{array}$ & Responden & $\begin{array}{l}\text { Sebelum } \\
\text { Perawatan } \\
\text { Luka }\end{array}$ & Keterangan & $\begin{array}{l}\text { Setelah } \\
\text { Perawatan } \\
\text { Luka }\end{array}$ & Keterangan \\
\hline $\begin{array}{l}\text { Minggu, } 6 \\
\text { juni } \\
2021\end{array}$ & $\begin{array}{c}2 \\
\text { Pukul } 10.00\end{array}$ & $\begin{array}{c}\text { Luka tampak } \\
\text { merah,eskuda } \\
\text { t seperti air, } \\
\text { kulit disekitar } \\
\text { luka berwar } \\
\text { na hitam }\end{array}$ & $\begin{array}{l}\text { Nilai:14 } \\
\quad \text { Tidak } \\
\text { Beregene } \\
\text { rasi }\end{array}$ & $\begin{array}{l}\text { Belum } \\
\text { ada } \\
\text { peruba } \\
\text { han }\end{array}$ & $\begin{array}{c}\text { Skor } \\
: 14 \\
\text { Tidak } \\
\text { Bergenerasi }\end{array}$ \\
\hline $\begin{array}{l}\text { Senin, } 7 \text { juni } \\
2021\end{array}$ & $\begin{array}{c}2 \\
\text { Pukul } 11.00\end{array}$ & $\begin{array}{l}\text { Luka tampak } \\
\text { merah, } \\
\text { sedikit } \\
\text { eskudat } \\
\text { berair, kulitdi } \\
\text { sekitar luka } \\
\text { berwarna } \\
\text { hitam }\end{array}$ & $\begin{array}{l}\text { Nilai:14 } \\
\text { Tidak } \\
\text { beregene } \\
\text { rasi }\end{array}$ & $\begin{array}{l}\text { Masih ada } \\
\text { Eskutdat } \\
\text { sepertiair }\end{array}$ & $\begin{array}{c}\text { Skor } \\
: 14 \\
\text { Tidak } \\
\text { Bergenerasi }\end{array}$ \\
\hline $\begin{array}{l}\text { Selasa, } 8 \\
\text { juni } \\
2021\end{array}$ & $\begin{array}{c}2 \\
\text { Pukul } 10.00\end{array}$ & $\begin{array}{c}\text { Luka tampak } \\
\text { merah,sedikit } \\
\text { eskudat } \\
\text { berair, kulit } \\
\text { di sekitar } \\
\text { luka } \\
\text { berwarna } \\
\text { hitam }\end{array}$ & $\begin{array}{l}\text { Nilai: } 14 \\
\text { Tidak } \\
\text { berege } \\
\text { nerasi }\end{array}$ & $\begin{array}{l}\text { Masih ada } \\
\text { Eskutdat } \\
\text { sepertiair }\end{array}$ & $\begin{array}{c}\text { Skor } \\
: 14 \\
\text { Tidak } \\
\text { Beregenerasi }\end{array}$ \\
\hline $\begin{array}{l}\text { Rabu, } 9 \text { juni } \\
2021\end{array}$ & $\begin{array}{c}2 \\
\text { Pukul } 09.35\end{array}$ & $\begin{array}{l}\text { Luka tampak } \\
\text { merah,sedikit } \\
\text {, eskudat } \\
\text { berair, kulitdi } \\
\text { sekitar luka } \\
\text { berwarna } \\
\text { hitam }\end{array}$ & $\begin{array}{l}\text { Nilai:14 } \\
\text { Tidak } \\
\text { Beregenera } \\
\text { si }\end{array}$ & $\begin{array}{l}\text { Masih ada } \\
\text { Eskutdat } \\
\text { sepertiair }\end{array}$ & $\begin{array}{c}\text { Skor: } \\
14 \\
\text { Tidak } \\
\text { bergenerasi }\end{array}$ \\
\hline $\begin{array}{l}\text { Kamis } 10 \\
\text { juni } 2021\end{array}$ & $\begin{array}{c}2 \\
\text { Pukul } 09.00\end{array}$ & $\begin{array}{c}\text { Luka tampak } \\
\text { merah, kulit } \\
\text { sekitar luka } \\
\text { berwarna } \\
\text { hitam }\end{array}$ & $\begin{array}{c}\text { Nilai:11 } \\
\text { Proses } \\
\text { penyembu } \\
\text { han }\end{array}$ & $\begin{array}{l}\text { Tidak ada } \\
\text { eskudat } \\
\text { sepertiair, } \\
\text { luka kering, }\end{array}$ & $\begin{array}{c}\text { Skor: } \\
11 \\
\text { Proses } \\
\text { penyembuh } \\
\text { an }\end{array}$ \\
\hline $\begin{array}{l}\text { Jumat,11 } \\
\text { juni } 2021\end{array}$ & $\begin{array}{c}2 \\
\text { Pukul } 09.00\end{array}$ & $\begin{array}{c}\text { Luka tampak } \\
\text { pink ,kulit di } \\
\text { sekitar luka } \\
\text { berwarna } \\
\text { hitam }\end{array}$ & $\begin{array}{c}\text { Nilai: } 11 \\
\text { Proses } \\
\text { penyembu } \\
\text { han }\end{array}$ & $\begin{array}{c}\text { Tidak ada } \\
\text { eskudat } \\
\text { sepertiair, } \\
\text { luka kering, }\end{array}$ & $\begin{array}{c}\text { Skor: } \\
\text { Proses } \\
\text { penyembuh } \\
\text { an }\end{array}$ \\
\hline
\end{tabular}


Sabtu, 12 juni 2021

Minggu, 13

juni 2021
$2 \quad$ Luka tampak Nilai:11

Pukul 10.00

$\begin{array}{cc}\text { pink, kulit di } & \text { Proses } \\ \text { sekitar luka } & \text { penyembu } \\ \text { berwarna } & \text { han } \\ \text { hitam } & \end{array}$

2

Pukul 09.48

Luka tampak Nilai: 10

pink ,kulit di

sekitar luka

warna hitam
Proses penyembu han

$\begin{array}{cc}\text { Tidak ada } & \text { Skor: } \\ \text { eskudat } & 11 \\ \text { sepertiair, } & \text { Proses } \\ \text { luka kering, } & \begin{array}{c}\text { penyembuh } \\ \text { an }\end{array}\end{array}$

Luka berwana Skor: putih, 10 eskudat Proses seperti berair penyembuh tidak ada, an luka kering, kulit sekitar luka masih berwarna hitaam

Hasil dari tabel 2 mengalami penurunan skor di hari ke 5, dari skor 14 menjadi 10 denganinterprestasi tidak proses penyembuhan

\section{Responden 3}

Tabel 3

Distribusi Pertemuan Pertama Pengkajian Luka dan Perawatan Luka Responden

$(\mathrm{n}=4)$ Sebelum dan Sesudah Perawatan Luka diwilayah Inpres IV Rw 06 Kelurahan Larangan utara Kecamatan Larangan Tangerang

\begin{tabular}{|c|c|c|c|c|c|}
\hline $\begin{array}{l}\text { Hari } \\
\text { Pertemuan } \\
1-8\end{array}$ & Responden & $\begin{array}{l}\text { Sebelum } \\
\text { Perawatan } \\
\text { Luka }\end{array}$ & Keterangan & $\begin{array}{c}\text { Sebelum } \\
\text { perawatan } \\
\text { luka }\end{array}$ & Keterangar \\
\hline $\begin{array}{l}\text { Minggu,14 } \\
\text { juni } \\
2021\end{array}$ & $\begin{array}{c}3 \\
\text { Pukul } 10.00\end{array}$ & $\begin{array}{l}\text { Luka masih } \\
\text { tertutup, } \\
\text { bau, } \\
\text { eskudat } \\
\text { berwarn } \\
\text { a kuning } \\
\text { kental, } \\
\text { dan } \\
\text { tampak } \\
\text { keras }\end{array}$ & $\begin{array}{c}\text { Nil } \\
\text { ai: } \\
20 \\
\text { Tidak } \\
\text { beregener } \\
\text { asi }\end{array}$ & $\begin{array}{l}\text { Belum ada } \\
\text { perubahan }\end{array}$ & $\begin{array}{c}\text { Skor: } \\
20 \\
\text { Tidak } \\
\text { beregene } \\
\text { rasi }\end{array}$ \\
\hline $\begin{array}{l}\text { Senin, } 15 \text { juni } \\
2021\end{array}$ & $\begin{array}{c}3 \\
\text { Pukul } 11.00\end{array}$ & $\begin{array}{c}\text { Luka } \\
\text { masih } \\
\text { tertutup, } \\
\text { bau, } \\
\text { eskudat } \\
\text { berwarna } \\
\text { kuning } \\
\text { kental, } \\
\text { dan } \\
\text { tampak } \\
\text { keras }\end{array}$ & $\begin{array}{c}\text { Nilai: } \\
20 \\
\text { Tidak } \\
\text { beregenera } \\
\text { si }\end{array}$ & $\begin{array}{l}\text { Bau } \\
\text { berkurang }\end{array}$ & $\begin{array}{c}\text { Skor: } \\
20 \\
\text { Tidak } \\
\text { beregene } \\
\text { rasi }\end{array}$ \\
\hline
\end{tabular}




\begin{tabular}{|c|c|c|c|c|c|}
\hline $\begin{array}{l}\text { Selasa, } 16 \\
\text { juni } \\
2021\end{array}$ & $\begin{array}{c}3 \\
\text { Pukul } 09.00\end{array}$ & $\begin{array}{l}\text { Luka } \\
\text { masih } \\
\text { tertutup, } \\
\text { bau, } \\
\text { eskudat } \\
\text { berwarna } \\
\text { kuni ng } \\
\text { kental, } \\
\text { dan } \\
\text { tampak } \\
\text { keras }\end{array}$ & $\begin{array}{c}\text { Nilai: } \\
20 \\
\text { Tidak } \\
\text { beregenera } \\
\text { si }\end{array}$ & $\begin{array}{l}\text { Bau } \\
\text { berkurang }\end{array}$ & $\begin{array}{c}\text { Skor: } \\
20 \\
\text { Tidak } \\
\text { beregenera } \\
\text { si }\end{array}$ \\
\hline $\begin{array}{l}\text { Rabu,17 juni } \\
2021\end{array}$ & $\stackrel{3}{3}$ Pukul 08.00 & $\begin{array}{c}\text { Luka } \\
\text { masih } \\
\text { tertutup, } \\
\text { bau, } \\
\text { eskudat } \\
\text { berwarna } \\
\text { kuning } \\
\text { kental, } \\
\text { dan } \\
\text { tampak } \\
\text { keras }\end{array}$ & $\begin{array}{c}\text { Nilai: } \\
20 \\
\text { Tidak } \\
\text { beregenera } \\
\text { si }\end{array}$ & $\begin{array}{c}\text { Eskudat } \\
\text { berwarna } \\
\text { kuning } \\
\text { sedikit } \\
\text { berkurang, } \\
\text { bau } \\
\text { berkurang }\end{array}$ & $\begin{array}{c}\text { Skor: } \\
20 \\
\text { Tidak } \\
\text { beregenera } \\
\text { si }\end{array}$ \\
\hline $\begin{array}{l}\text { Kamis } 18 \\
\text { juni } 2021\end{array}$ & $\begin{array}{c}3 \\
\text { Pukul } \\
07.00\end{array}$ & $\begin{array}{l}\text { Luka } \\
\text { sudah } \\
\text { terbuka, } \\
\text { luka } \\
\text { berwana } \\
\text { merah } \\
\text { dan lunak }\end{array}$ & $\begin{array}{c}\text { Nilai: } \\
16 \\
\text { Tidak } \\
\text { beregenera } \\
\text { si }\end{array}$ & $\begin{array}{c}\text { Eskudat } \\
\text { kuning } \\
\text { kental sudah } \\
\text { tidak ada, } \\
\text { sudah tidak } \\
\text { bau }\end{array}$ & $\begin{array}{c}\text { Skor: } \\
16 \\
\text { Tidak } \\
\text { beregenera } \\
\text { si }\end{array}$ \\
\hline $\begin{array}{l}\text { Jumat,19 } \\
\text { juni } 2021\end{array}$ & $\begin{array}{c}3 \\
\text { Pukul } \\
08.45\end{array}$ & $\begin{array}{l}\text { Luka } \\
\text { sudah } \\
\text { terbuka, } \\
\text { luka } \\
\text { berwana } \\
\text { merah } \\
\text { dan lunak }\end{array}$ & $\begin{array}{c}\text { Nilai: } \\
16 \\
\text { Tidak } \\
\text { Beregenera } \\
\text { si }\end{array}$ & $\begin{array}{c}\text { Eskudat } \\
\text { kuning } \\
\text { kental sudah } \\
\text { tidak ada, } \\
\text { sudah tidak } \\
\text { bau }\end{array}$ & $\begin{array}{c}\text { Skor: } \\
16 \\
\text { Tidak } \\
\text { beregenera } \\
\text { si }\end{array}$ \\
\hline $\begin{array}{l}\text { Sabtu,20 juni } \\
2021\end{array}$ & $\begin{array}{c}3 \\
\text { Pukul } 09.47\end{array}$ & $\begin{array}{l}\text { Luka } \\
\text { sudah } \\
\text { terbuka, } \\
\text { luka } \\
\text { berwana } \\
\text { pink }\end{array}$ & $\begin{array}{c}\text { Nilai: } \\
16 \\
\text { Tidak } \\
\text { beregenera } \\
\text { si }\end{array}$ & $\begin{array}{c}\text { Eskudat } \\
\text { kuning } \\
\text { kental sudah } \\
\text { tidak ada, } \\
\text { sudah tidak } \\
\text { bau, luka } \\
\text { berwarna } \\
\text { pink }\end{array}$ & $\begin{array}{c}\text { Skor: } \\
16 \\
\text { Tidak } \\
\text { Beregenera } \\
\text { si }\end{array}$ \\
\hline $\begin{array}{l}\text { Minggu, } 21 \\
\text { juni } 2021\end{array}$ & $\begin{array}{c}3 \\
\text { Pukul } 07.30\end{array}$ & $\begin{array}{l}\text { Luka } \\
\text { sudah } \\
\text { terbuka, } \\
\text { luka } \\
\text { berwana } \\
\text { pink }\end{array}$ & $\begin{array}{c}\text { Nilai; } \\
16 \\
\text { Tidak } \\
\text { beregenera } \\
\text { si }\end{array}$ & $\begin{array}{c}\text { luka } \\
\text { berwarna } \\
\text { pink,Eskudat } \\
\text { berwarna } \\
\text { kuning } \\
\text { sudah tidak } \\
\text { ada, sudah } \\
\text { tidak bau }\end{array}$ & $\begin{array}{c}\text { Nilai; } \\
16 \\
\text { Tidak } \\
\text { beregenera } \\
\text { si }\end{array}$ \\
\hline
\end{tabular}


Hasil dari table 3 mengalami penuruna skor di hari ke 5, dari skor 20 menjadi 16 dengan interprestasi tidak bergenerasi.

\section{Responden 4}

Tabel 4

Distribusi Pertemuan Pertama Pengkajian Luka dan Perawatan Luka Responden

$(n=4)$ Sebelum dan Sesudah Perawatan Luka diwilayah Inpres IV Rw 06 Kelurahan

Larangan Utara Kecamatan Larangan Tangerang

\begin{tabular}{|c|c|c|c|c|c|}
\hline $\begin{array}{l}\text { Hari } \\
\text { Pertemuan } 1\end{array}$ & Responden & $\begin{array}{l}\text { Sebelum } \\
\text { Perawatan } \\
\text { Luka }\end{array}$ & Keterangan & $\begin{array}{c}\text { Setelah } \\
\text { perawatan } \\
\text { luka }\end{array}$ & Keterangan \\
\hline $\begin{array}{l}\text { Minggu,14 } \\
\text { juni } \\
2021\end{array}$ & $\begin{array}{c}4 \\
\text { Pukul } \\
10.00\end{array}$ & $\begin{array}{c}\text { Luka } \\
\text { tampak } \\
\text { berwarna } \\
\text { merah } \\
\text { muda, } \\
\text { bau, } \\
\text { easkudat } \\
\text { berwarna } \\
\text { kuning }\end{array}$ & $\begin{array}{c}\text { Nilai:22 } \\
\text { Tidak } \\
\text { beregenera } \\
\text { si }\end{array}$ & $\begin{array}{l}\text { Belum ada } \\
\text { perubahan }\end{array}$ & $\begin{array}{c}\text { Skor: } \\
22 \\
\text { Tidak } \\
\text { beregenera } \\
\text { si }\end{array}$ \\
\hline $\begin{array}{l}\text { Senin, } 15 \text { juni } \\
2021\end{array}$ & $\begin{array}{c}4 \\
\text { Pukul } \\
11.00\end{array}$ & $\begin{array}{c}\text { Luka } \\
\text { tampak } \\
\text { berwarna } \\
\text { merah, } \\
\text { bau, } \\
\text { easkudat } \\
\text { seperti air }\end{array}$ & $\begin{array}{c}\text { Nilai:22 } \\
\text { Tidak } \\
\text { beregenera } \\
\text { si }\end{array}$ & $\begin{array}{c}\text { Bau } \\
\text { sedikit } \\
\text { berkurang, } \\
\text { Eskudat } \\
\text { sedikit } \\
\text { berkurang }\end{array}$ & $\begin{array}{c}\text { Skor: } \\
22 \\
\text { Tidak } \\
\text { beregenera } \\
\text { si }\end{array}$ \\
\hline $\begin{array}{l}\text { Selasa, } 16 \text { juni } \\
2021\end{array}$ & $\begin{array}{c}4 \\
\text { Pukul } \\
09.00\end{array}$ & $\begin{array}{c}\text { Luka } \\
\text { tampak } \\
\text { berwarna } \\
\text { merah, } \\
\text { bau, } \\
\text { easkudat } \\
\text { berwarna } \\
\text { kuning }\end{array}$ & $\begin{array}{c}\text { Nila } \\
\text { i:22 } \\
\text { Tidak } \\
\text { beregenera } \\
\text { si }\end{array}$ & $\begin{array}{c}\text { Bau sedikit } \\
\text { berkurang, } \\
\text { Eskudat } \\
\text { sedikit } \\
\text { berkurang }\end{array}$ & $\begin{array}{c}\text { Skor: } \\
22 \\
\text { Tidak } \\
\text { beregenera } \\
\text { si }\end{array}$ \\
\hline $\begin{array}{l}\text { Rabu, } 17 \text { juni } \\
2021\end{array}$ & $\begin{array}{c}4 \\
\text { Pukul } \\
08.33\end{array}$ & $\begin{array}{c}\text { Luka } \\
\text { tampak } \\
\text { berawrna } \\
\text { merah } \\
\text { bau, } \\
\text { eskudat } \\
\text { berwarna } \\
\text { kuning. }\end{array}$ & $\begin{array}{l}\text { Nilai:22 } \\
\text { Tidak } \\
\text { beregene } \\
\text { rasi }\end{array}$ & $\begin{array}{c}\text { Bau sedikit } \\
\text { berkurang, } \\
\text { Eskudat } \\
\text { sedikit } \\
\text { berkurang }\end{array}$ & $\begin{array}{c}\text { Skor: } \\
22 \\
\text { Tidak } \\
\text { beregene } \\
\text { rasi }\end{array}$ \\
\hline $\begin{array}{l}\text { Kamis } 18 \text { juni } \\
2021\end{array}$ & $\begin{array}{c}4 \\
\text { Pukul } \\
08.30\end{array}$ & $\begin{array}{l}\text { Luka } \\
\text { tampak } \\
\text { merah, } \\
\text { eskudat } \\
\text { berwarna } \\
\text { kuning } \\
\text { sedikit }\end{array}$ & $\begin{array}{c}\text { Nilai: } 20 \\
\text { Tidak } \\
\text { beregene } \\
\text { rasi }\end{array}$ & $\begin{array}{c}\text { Eskudat } \\
\text { sedikit } \\
\text { berkuran } \\
\mathrm{g}\end{array}$ & $\begin{array}{c}\text { Skor: } \\
20 \\
\text { Tidak } \\
\text { beregene } \\
\text { rasi }\end{array}$ \\
\hline
\end{tabular}


TAHUN [MANUJU: MALAHAYATI NURSING JOURNAL, ISSN CETAK: 2655-2728

\begin{tabular}{|c|c|c|c|c|c|}
\hline $\begin{array}{l}\text { Jumat } 19 \text { juni } \\
2021\end{array}$ & $\begin{array}{c}4 \\
\text { Pukul } \\
07.00\end{array}$ & $\begin{array}{c}\text { Luka } \\
\text { tampak } \\
\text { merah, } \\
\text { moist, } \\
\text { luka } \\
\text { tampak } \\
\text { lembab, } \\
\text { eskudat } \\
\text { tidak } \\
\text { teramati }\end{array}$ & $\begin{array}{c}\text { Nilai: } 18 \\
\text { Tidak } \\
\text { beregene } \\
\text { rasi }\end{array}$ & $\begin{array}{l}\text { Sudah } \\
\text { tidakada } \\
\text { eskudat }\end{array}$ & $\begin{array}{c}\text { Skor: } \\
18 \\
\text { Tidak } \\
\text { beregene } \\
\text { rasi }\end{array}$ \\
\hline $\begin{array}{l}\text { Sabtu 20juni } \\
2021\end{array}$ & $\begin{array}{c}4 \\
\text { Pukul } \\
08.00\end{array}$ & $\begin{array}{l}\text { Luka } \\
\text { tampak } \\
\text { merah, } \\
\text { moist, } \\
\text { luka } \\
\text { tampak } \\
\text { lembab }\end{array}$ & $\begin{array}{l}\text { Nilai:18 } \\
\text { Tidak } \\
\text { beregene } \\
\text { rasi }\end{array}$ & $\begin{array}{l}\text { Sudah } \\
\text { tidak ada } \\
\text { eskudat }\end{array}$ & $\begin{array}{c}\text { Skor : } \\
18 \\
\text { Tidak } \\
\text { beregener } \\
\text { a si }\end{array}$ \\
\hline $\begin{array}{l}\text { Minggu } 21 \\
\text { juni } 2021\end{array}$ & $\begin{array}{c}4 \\
\text { Pukul } 07.30\end{array}$ & $\begin{array}{l}\text { Luka } \\
\text { tampak } \\
\text { pink, } \\
\text { luka } \\
\text { kering. }\end{array}$ & $\begin{array}{c}\text { Nilai: } \\
17 \\
\text { Tidak } \\
\text { Berege } \\
\text { nerasi }\end{array}$ & $\begin{array}{l}\text { Luka } \\
\text { berwarna } \\
\text { pink, luka } \\
\text { tampak } \\
\text { kering, } \\
\text { tidak } \\
\text { ada bau, } \\
\text { eskudat } \\
\text { tidak ada }\end{array}$ & $\begin{array}{c}\text { Skor: } \\
17 \\
\text { Tidak } \\
\text { Berege } \\
\text { nerasi }\end{array}$ \\
\hline
\end{tabular}

Hasil dari table 1 mengalami perubahan di hari ke 5 , dari skor
22 menjadi 17 dengan interprestasi tidak bergenerasi 


\section{PEMBAHASAN}

Data hasil analisismengenai lansia terdapat penderita diabetes melitusyang memiliki luka, sebelum perawatan luka menggunakan metode modern dressing kepada 4 responden didapatkan data deengan stadium $0(0 \%)$, stadium I ( $50 \%)$, stadium II (50\%), stadium III 0 $(0 \%)$, stadium IV (0\%), stadium $5(0 \%)$.

Modern Dressing menggunakan konsep lembab denganperawatan luka tertutup tanpa terkecuali, semua jenis luka kronik dan akut menggunakan perawatan luka dengan tertutup. Arisanty tahun (2012) juga menyatakan bahwa luka yang mengalami keterlambatan dalam proses penyembuhan luka diakibatkan oleh faktor yang menghambat proses penyembuhan sehingga luka lama sembuh diakibatkan penyakit penyerta (penyakit gula, penyumbatan pembuluh darah arteri, permasalahan pembuluh darah vena, dan imobilisasi.(Nurhaida 2015).

Menurut penelitian Yoland (2017). Jaringan nekrotik inilah yang menghambat proses penyembuhan luka. Proses penyembuhan luka akan berlangsung, apabila pengangkatan jaringan nekrotik (debrimen) berhasil.

Ukuran luka diabetes setelah dilakuakan perawatan lukamodern dressing sebanyak 8 kali dalam delapan hari hingga hari ke 8.

Semula respondentidak ada yang memiliki luas luka lebih dari $4 \mathrm{~cm}^{2}$ setelah dilakukan intervensi Responden 1 di hari pertama luas luka $6 \mathrm{Cm}^{2}$ skor BWAT 33. Responden 2 di hari pertama luas luka $4 \mathrm{Cm}^{2}$ dengan kondisi luka pada awal intervensi luka dengan skor BWAT 14.

Responden 3 di hari pertama luas luka $4 \mathrm{Cm}^{2}$ pada awal intervensi luka dengan skor BWAT 20. Responden 4 di hari pertama luas luka $4 \mathrm{Cm}^{2}$ pada awal intervensi luka dengan skor BWAT 33. Setelah dilakukan intervensi perawatan luka modern dressing didapatkan bahwa 4 responden mengalami penurunan nilai skor BWAT.

Dengan data responden 1 nilai skor Bwat dari 33 menjadi 27, kemudian responden 2 nilai skor BWAT dari 14 menjadi10, responden 3 nilai skor BWAT dari 20 menjadi 16, dan responden 4 nilai skor BWATdari 22 menjadi 17. Maka peneliti menyimpulkan bahwa

4 responden 3 responden mengalami prosespenyembuhan, namun 1 responden tidak mengalami proses penyembuhan (tidak beregenerasi).

Faktor berat dan ringannya luka berpengaruh terhadap lama penyembuhan. Semakin berat luka yang dialami padaresponden dengan Diabetes Mellitus, maka akan semakin memperpanjang lamapenyembuhan luka. (Effendi atal., 2020).

Sejalan dengan penelitian (Yolanda, 2017) Hidroaktifmampu melakukan proses peluruhan jaringan nekrotik oleh tubuh sendiri. Hydrogel banyak mengandung air,yang kemudian akan membuatsuasana luka yang tadinyakering karena jaringan nekrotik menjadi lembab, Pada usia lanjut fungsi tubuh secara fisiologi menurun, hal ini disebabkan karena penurunan sekresi atau retensi insulin, sehingga kemampuan fungsi tubuh terhadappengendalian glukosa darahyang tinggi kurang optimal(Ferawati, 2014).

Peningkatanaliran darah ke daerah yangrusak, membersihkan sel danbenda asing adalah awal dari perubahan yang ditandai dengan proses penyembuhan luka(Mariyunani, 2015).

Peneliti menyimpulkan bahwa proses penyembuhan luka padapasien luka ulkus 
diabetik belum mengalami perubahan dan masih dalam proses perbaikan.

\section{KESIMPULAN}

Hasil analisis intervensi yang dilakukan pada tiga responden perawatan luka Modern Dressing tidak bergenerasi dan saturesponden mengalami proses penyembuhan, hal ini terlihat penjelasan secara rinci.

Penerapan Intervensi perawatan luka Modern Dressing berpengaruh padaluka diabetes dibuktikan dengan data karateristik penderita diabetes melitus yaitu usia diatas 60 tahun, disebabkan oleh pola makan/nutrisi, perilaku tidak sehat, kurang aktifitas fisik danstress.

Perawatan luka modern dressing yang dilakukan selam 8 hari berturut-turut berpengaruh dalam pelayanan dan asuhan keperawatan lansia dengan maslah DM yang memiliki luka serta mengidentifikasi adayanya proses penembuhan yang ditandai dengan penurunan nilai skala BWAT sebelum dan sesudah intervensi perawatan. Responden 2 mengalami proses penyembuhan luka diabetic lebih bagus disbanding responden satu, tiga dan empat yang disebabkan oleh faktor usia.

Implementasi perawatan

\section{DAFTAR PUSTAKA}

Ali Maghfuri. Buku Pintar Perawatan Luka Diabates Melitus. Jakarta: Salemba Medika (2016).

Arisanty, I., P. (2012). Panduan Praktis Pemilihan Balutan Luka Kronik. Jakarta: Mitra luka dengan metode modern dressing telah meningkatkan pemahaman dan kemampuan lansia di keluarga dalam melakukan tindakan perawatan luka yang telah di ajarkan.

\section{SARAN}

Bagi Pengambil KebijakanKesehatan Bagi Puskesmas Larangan Utara dapat mempertimbangkan untuk melakukan intervensi Perawatan luka Modern Dressing ini sebagai penatalaksanaan pasien dalam program pelayanan puskesmas.

Bagian Institusi Pendidikan

Keperawatan Dapat menambah pengetahuan pemahaman dan memberikan gambaran di institusi pendidikan mengenai manfaat modern dressing terhadap penyembuhan luka. Metode Modern Dressing dapat menjadi salah satu bahan materi yang dapat di berikan bagi mahasiswa untuk memperluas wawasan dalam intervensi keperawatan gerontik khususnya pada lansiapenderita diabetes dengan luka.

Bagi Peneliti Selanjutnya. Perlu diharapkan penelitian inidapat dijadikan sebagaievidence based dan tambahan informasi untuk mengembangkan penelitianlebih lanjut dalam melakuakn perawatan luka metode Modern Dressing.

Bagi keluarga dan lansia Melanjutkan pengelolaan lansia secara mandiri guna mempertahankan kualitas hidupnya dan keluarga terus mendampingi untuk melanjutkan intervensiperawatan luka denganMetode Modern Dresing sebagaiupaya pencegahan penderita Diabetes melitus dengan luka pada lansia.

Wacana Medika.

Basuki, H. Pengaruh Akses Pelayanan Kesehatan. Buletin Penelitian Sistem Kesehatan.(2017).

Data Puskesmas, Kecamatan Larangan Utara Data diabetes melitus utara (2020)

Dariah, E. D \& Okatiranti Hubungan 
Kecemasan Dengan Kualitas Tidur Lansia Di Posyandu Anyelir Kecamatan Cisarua Kabupaten Bandung Barat. Jurnal IImu Keperawatan Bandung:Universitas BSI

Volume III, No. 2, September (2015)

Damsir, Analisis Manajemen Perawatan Luka Pada Kasus luka Diabetik di Instalasi Gawat Darurat (IGD)Rumah Sakit Arifin Nu'mang Kabupaten Sidrap. Windows of Health: Jurnal Kesehatan, Vol.1 No. 2. (2018).

Ferawati. (2014). Hubungan Dukungan Keluarga Dan Perilaku Pengelolaan Penyakit Diabetes Melitus Tipe 2 Di Wilayah Kerja Puskesmas Purnama Kecamatan Pontianak Selatan Kota Pontianak.
Jurnal Mahasiswa PSPD FK Universitas Tanjungpura, (Vol 1, No 1 (2014).

Maryunani Anik,(2013). Perawatan Luka (Modern Woundcare) Terkini dan Terlengkap. Bogor : IN MEDIA

Nurhaida,Gambaran Efektifitas Perawatan Luka Diabetik Dengan Menggunakan Modern Dressing Dan Konvensional Diasri Wound Care Center Dan R.S.U Martha Friska medan jurnal ilmiah, Vol.11 No.3 Januari-April 181-182 (2015).

Nurhaida, Gambaran Efektifitas Perawatan Luka Diabetik Dengan Menggunakan Modern Dressing Dan Konvensional Diasri Wound Care Center Dan R.S.U Martha Friska medan jurnal ilmiah ,Vol.11 No.3 Januari-April 181-182 (2017).

Yoland.S Pengaruh metode rawat luka dengan terapi hiperbarik terhadap proses penyembuhan luka ulkus diabetic pada pasein diabetes melitus. (2017). 